\title{
Clinical applications of vibration therapy in orthopaedic practice
}

\author{
Simone Cerciello ${ }^{1,2}$ \\ Silvio Rossi ${ }^{3}$ \\ Enrico Visonà ${ }^{4}$ \\ Katia Corona ${ }^{5}$ \\ Francesco Oliva ${ }^{6}$ \\ 1 Casa di Cura Villa Betania, Rome, Italy \\ 2 Marrelli Hospital, Crotone, Italy \\ 3 Rome American Hospital, Rome, Italy \\ 4 Ospedali Riuniti Padova Sud, ULSS 17, Padova, \\ Italy \\ 5 Università degli Studi del Molise, Campobasso, Italy \\ 6 University of Rome "Tor Vergata", School of \\ Medicine, Rome, Italy
}

Corresponding author:

Enrico Visonà

Ospedali Riuniti Padova Sud, ULSS 17

Via Albere 30, Monselice

35043 Monselice (PD), Italy

E-mail: enricovisona@icloud.com

\section{Summary}

Background: Vibration therapy (VT) has been proposed as an option to improve physical performance and reduce the negative effects of ageing on bone, muscles and tendons. Several discrepancies exist on the type of applications, frequency and magnitude. These differences reflex on the contradictory clinical results in literature. Aim of the present study is to carry on an exhaustive review to focus on technical options on the market, clinical applications in orthopaedic practice and expected outcomes.

Methods: a literature review using the key words "vibration therapy" and "whole-body vibration" and "orthopaedics" was performed. After checking the available abstracts 71 full text articles were evaluated.

Results: fifty-one articles focused on the effects of VT on muscles and tendons reporting ways of action and clinical outcomes. In a similar way 20 studies focused on the influence of VT on bone tissue with regard on ways of action and clinical trials.

Conclusions: VT provides anabolic mechanical signals to bone and musculo-tendinous system. The best effects seem to be achieved with de- vices that deliver low-intensity stimuli at high frequencies providing linear horizontal displacement.

KEY WORDS: aged, athletes, electric stimulation therapy, osteoporosis, physical therapy modalities, rehabilitation.

\section{Introduction}

Disuse and aging are responsible for bone density decrease, loss of skeletal strength and muscle dysfunction. These effects may have severe impact on quality of life and social costs. In an opposite way it has been proven that bone and muscle tissues are influenced and respond to local dynamic loading ${ }^{1}$. This effect can be used to compensate the atrophy induced by disuse and aging or to improve bone and muscular function. The human body is daily exposed to relatively few low-frequency $(1-3 \mathrm{~Hz})$, large-magnitude (2000-3000 microstrain) events but is subject to several high-frequency $(10-50 \mathrm{~Hz})$, low-magnitude signals (postural muscle contractions) ${ }^{2}$. Vibration therapy (VT) consisting of low-magnitude high-intensity (LIV) stimuli represents a good way to safely deliver relevant mechanical signals to patients who cannot exercise to build musculoskeletal strength ${ }^{3}$. Two wide categories of vibrating devices are actually available on the market: the so-called whole-body vibration (WBV) devices and vibration devices locally applied on a single muscle. Both are based on a mechanical stimulation characterized by frequency (in $\mathrm{Hz}$ ) and amplitude of the oscillation induced (peak to peak displacement in $\mathrm{mm}$ ) but they widely differ in terms of clinical applications. WBV applications have a vibration frequency in the range $20-50 \mathrm{~Hz}$ whereas local application to specific muscular district tolerates a much higher frequency range (around 300$500 \mathrm{~Hz})^{4}$. Since the vibration can be applied with a wide spectrum of frequencies and settings ${ }^{5}$ different effects on healthy and pathologic tissues are possible. Most common applications are: pain control6,7, improvement of muscle force and flexibility ${ }^{8}$, reduction of fatigue onset and accelerate rehabilitation ${ }^{9-11}$ and increase bone density ${ }^{12}$. However only a few studies described specific vibrational training protocols, and this lack of information generates uncertainties regarding the most effective vibration intensities, frequencies, and application protocols. This reflects the wide controversy regarding expected out- 
comes. Aim of the present review is to analyze the available literature concerning vibration therapy with particular emphasis for its ways of action and clinical applications.

\section{Materials and methods}

A comprehensive literature review using the keywords "vibration therapy" and "whole-body vibration" and "orthopaedics" with no limit regarding the year of publication was performed. The following databases were accessed on 10 August 2015 PubMed (http:// www.ncbi.nlm.nih.gov/sites/entrez/); Ovid (http://www. ovid.com); Cochrane Reviews (http://www.cochrane. org/reviews/), Google Scholar. 109 publications were identified. All the abstracts were reviewed by a single Author (SC). The full text papers were then selected or excluded according to the abstract text, excluding the article if an abstract was not available and the language was not English. In addition, the reference lists of the studies included were searched by hand to include articles not identified through the databases (n.56). At the end 71 articles were evaluated.

In accordance with international standards and as required by this Journal, Authors declare that the study meets the ethical standards of this Journal13.

\section{Results}

Fifty-one articles focused on the effects of VT on muscles and tendons. Ways of action were thoroughly analyzed and explained in 16 studies while the outcomes of clinical trials were reported in 33 studies. They included results on healthy active subjects in 21 cases, elderly patients in 13 and children in 1 . Twenty articles focused on the influence of VT on bone tissue with regard on ways of action and clinical trials. Seven studies investigated the possible mechanisms of action on bone metabolism; 11 reported the effects of VT in postmenopausal subjects, whereas 2 articles focused on the effects in disabled osteopenic children.

\section{Discussion}

\section{Muscle function}

The applications of WBV on muscle mass and function in trained athletes have been widely investigated in the past years ${ }^{14,15}$ whereas the effects of local vibrations have received less attention. Vibrational stimuli (VS) have an important impact on muscle function both in young subjects and elderly patients.

\section{Ways of action}

VS can induce non-voluntary muscular contraction through the phenomenon of tonic vibration reflex $(T V R)^{16}$. This is caused by the activation of the proprioceptive sensory system, which is based on the excitation of la afferent signals from the neuromuscu- lar spindle (which respond to variations in length). These signals activate the a-motoneurons leading to recruitment of previously inactive muscle fibers ${ }^{17}$. Additionally VS, may also affect Golgi tendinous organs (GTO), which are sensitive to variation in tension ${ }^{18}$. Finally VS may inhibit the agonist-antagonist co-activation mediated by la-inhibitory neurons ${ }^{19}$. The final outcome is an increase in the contractive force of stimulated $^{20}$ and adjacent synergistic muscles ${ }^{21}$. Apart from the direct effect on muscle activation, VS seems to induce a stimulation of spinal and supraspinal functions, leading to better nervous control of muscular fiber recruitment ${ }^{22}$. This aspect has been confirmed by lodice et al., who highlighted the role of sensory nervous system activation ${ }^{23}$. Local effects of VS such as muscle mass increase ${ }^{24}$, or mechanical effects on muscle cross-bridges ${ }^{25}$ are transitory and limited. Whereas according to the evidence of positive effects of proprioceptive training on muscle strength and function 26,27 , the main effect of VS could be related to a better central processing mechanism of afferent signals.

In addition it has been demonstrated that vibration enhances expression of anabolic genes in tendons ${ }^{28}$. Finally, part of the effect exerted by WBV on muscles and tendons could be related to variations in the endocrine system function. At this level it has been demonstrated an increase in the serum concentrations of growth hormone $(\mathrm{GH})$ and testosterone, and a decrease in cortisol after WBV applications ${ }^{15,20,23}$. Variations in $\mathrm{GH}$ levels could be the consequence of increased gravitational loads produced by the vibrating platform ${ }^{5}$.

\section{Clinical applications: muscle training}

Although it has been clearly demonstrated an effect of VS on muscle function, this widely changes according to the duration and intensity of application (Tab. 1). The effects of an acute application such as a single WBV session, include an increase in maximal muscle force, power output, and jump performance 20,29-31. Conversely Rittweger et al. found a decrease in jump performance ${ }^{32}$ and De Ruiter et al. reported a decline of $7 \%$ in the maximal isometric voluntary contraction (MVC) of the knee extensor muscles 90 s after a single WBV training session ${ }^{33}$.

Continuous application of WBV may indeed have negative effects rather than positive. Prolonged exposure seems to reduce muscle force and increase fatigue onset ${ }^{7,34,35}$. De Ruiter et al. reported the effects of $30 \mathrm{~Hz}$ WBV over a period of 11 weeks in young subjects stating that neither the strength nor the contractile properties of the knee extensor muscle improved $^{33}$. Jackson et al. showed that prolonged exposition (30 min at $30 \mathrm{~Hz}$ ) significantly attenuated muscle strength and EMG activity ${ }^{36}$. Conversely, some Authors reported positive effects ${ }^{23}, 37$. lodice et al. reported that local application of high-frequency VS resulted in significant improvement of muscle performance after several weeks, however some hormonal variations and minor performance improvements were found after a single session ${ }^{23}$. 
Table 1. Clinical applications of WBV: muscle training.

\begin{tabular}{|c|c|c|c|c|c|}
\hline Author & $\begin{array}{l}\text { n. of } \\
\text { patients }\end{array}$ & $\begin{array}{l}\text { Type of } \\
\text { vibration }\end{array}$ & Duration & $\begin{array}{l}\text { Control } \\
\text { group }\end{array}$ & Outcome \\
\hline Bongiovanni $1990^{7}$ & 25 & $150 \mathrm{~Hz}$ & $2 \min$ & no & Depression of EMG activity \\
\hline Bosco $1999^{29}$ & 12 & $30 \mathrm{~Hz}$ & $5 \times 1 \mathrm{~min}$ & $\begin{array}{l}\text { n.12 control } \\
\text { group }\end{array}$ & $\begin{array}{l}\text { Increased neural activity } \\
\text { and muscle power }\end{array}$ \\
\hline Issurin $1999^{30}$ & 28 & $44 \mathrm{~Hz}$ & $6-7 \mathrm{sec}$ & no & $\begin{array}{l}\text { No increase in maximal and } \\
\text { mean power }\end{array}$ \\
\hline Bosco $2000^{20}$ & 14 & $26 \mathrm{~Hz}$ & $10 \times 1 \min$ & no & $\begin{array}{l}\text { Increased of T and GH, } \\
\text { Decreased C }\end{array}$ \\
\hline Rittweger $2000^{32}$ & 37 & $26 \mathrm{~Hz}$ & & no & $\begin{array}{l}\text { Elicits a mild cardiovascular } \\
\text { exertion }\end{array}$ \\
\hline Torvinen $2002^{31}$ & 16 & $15-30 \mathrm{~Hz}$ & $4 \mathrm{~min}$ & no & $\begin{array}{l}\text { Transiently improves } \\
\text { muscle performance }\end{array}$ \\
\hline Jackson $2003^{36}$ & 10 & $30-120 \mathrm{~Hz}$ & $30 \mathrm{~min}$ & no & Reduction in maximal force \\
\hline De Ruiter $2003^{33}$ & 12 & $30 \mathrm{~Hz}$ & $5 \mathrm{X} 1 \mathrm{sec}$ & no & $\begin{array}{l}\text { No improvement in muscle } \\
\text { activation }\end{array}$ \\
\hline Mottram 2006 ${ }^{34}$ & $\begin{array}{l}\mathrm{n} .25 \\
\text { suprathreshold }\end{array}$ & $100 \mathrm{~Hz}$ & 5 see & $\begin{array}{l}\text { n.25 } \\
\text { subthreshold } \\
\text { n.25 control } \\
\text { group }\end{array}$ & $\begin{array}{l}\text { Reduced time to failure of a } \\
\text { sustained contraction }\end{array}$ \\
\hline lodice $2011^{23}$ & 18 & $300 \mathrm{~Hz}$ & $30 \mathrm{~min}$ & $\begin{array}{l}\mathrm{n} .18 \\
\text { resistance } \\
\text { program }\end{array}$ & $\begin{array}{l}\text { Improved neuromuscular } \\
\text { performance }\end{array}$ \\
\hline
\end{tabular}

C: cortisol

$\mathrm{T}$ : testosteron

G: growth hormone

\section{Clinical applications: muscle soreness}

Delayed-onset muscle soreness has been defined as disabling pain occurring 24-72 hours after unaccustomed or unfamiliar exercise. Several pathogenic theories have been proposed including connective tissue damage theory, muscle damage theory, inflammation theory and enzyme efflux theory. Some studies have investigated the role of WBV in the control of muscle soreness after physical activity (Tab. 2). In the majority of the cases WBV resulted in decreased DOMS and tightness and increased flexibility and muscle power when compared to control treatment ${ }^{38-43}$. Manimmanakorn et al. in a randomized study reported that WBV increased muscle oxygenation ${ }^{44}$. Wheeler et al. found no differences in terms of DOMS, muscle flexibility, or explosive power when WBV was compared to light exercise program ${ }^{45}$. In addition VS has proven to be effective on hamstring thightness as demonstrated in a recent review by Houston et al. ${ }^{8}$.

\section{Clinical applications: elderly patients}

The normal senescence process affects the whole body with decrease of muscular performance, balancing ability and coordination and reduction of bone density. This process involves muscle composition and function, starting from the age of $30-40$, with an increased loss after the age of 75 . The isometric voluntary contraction decreases by $25 \%$ at age 65 , and by $35 \%$ at the age of 70 years ${ }^{46}$. The sarcopenia has critical impact on the quality of life since it is cause of disability and weakness ${ }^{47}$, with unstable balance, inability to ascend and descend stairs, or take the shopping bags home, all contributing to impairment of quality of life. Several methods have been proposed to attenuate this physiologic process including WBV (Tab. 3). Resistance training is an effective method to reduce the effects of sarcopenia. The effects of training programs on elderly subjects are comparable to those obtained in healthy adults. Frontera et al. showed an increase of the muscle mass and strength after 12 weeks of high intensity resistance training ${ }^{48}$, with similar effects on elderly women. In a similar way, Pietrangelo et al. found increased muscle force, without signs of hypertrophy, in elderly subjects treated with HLV for 12 weeks ${ }^{4}$. Similar effects on muscular contractile properties in elderly have been widely reported in several clinical studies ${ }^{49-51}$. Other studies support that WBV has the potential to enhance the effects of physiscal training. Four months of high-intensity vibration $(30-50 \mathrm{~Hz}, 2-2.8 \mathrm{~g})$ combined with resistance exercises in postmenopausal women enhanced muscular strength compared with resistance training alone at multiple sites ${ }^{52}$. In a similar way Bogaerts et al. compared the outcomes of WBV in a group of elderly patients to those of fitness training and sham therapy ${ }^{53}$. WBV training resulted in an increase iso- 
Table 2. Clinical applications of WBV: musclesoreness.

\begin{tabular}{|c|c|c|c|c|c|}
\hline Author & $\begin{array}{l}\text { n. of } \\
\text { patients }\end{array}$ & $\begin{array}{l}\text { Type of } \\
\text { vibration }\end{array}$ & Duration & Control group & Outcome \\
\hline Rhea $2009^{38}$ & 8 & $35+50 \mathrm{~Hz}$ & $1 \min X 2$ & $\begin{array}{l}\text { n. } 8 \text { control } \\
\text { group }\end{array}$ & $\begin{array}{l}\text { Reduced } \\
\text { musclesoreness } \\
\text { and tightness }\end{array}$ \\
\hline Broadbent $2010^{41}$ & 15 & $40 \mathrm{~Hz}$ & $1 \min \times 3$ & $\begin{array}{l}\text { n.14 Control } \\
\text { group }\end{array}$ & $\begin{array}{l}\text { Reduced } \\
\text { musclesoreness } \\
\text { and IL6 levels }\end{array}$ \\
\hline Lau $2011^{40}$ & 15 & $65 \mathrm{~Hz}$ & $30 \mathrm{~min}$ & $\begin{array}{l}\text { n.15 control } \\
\text { group }\end{array}$ & $\begin{array}{l}\text { Decreased } \\
\text { soreness }\end{array}$ \\
\hline Aminian-Far $2011^{39}$ & 15 & $35 \mathrm{~Hz}$ & $60 \mathrm{sec}$ & $\begin{array}{l}\mathrm{n} .17 \text { control } \\
\text { group }\end{array}$ & $\begin{array}{l}\text { Reduced DOMS } \\
\text { via muscle } \\
\text { function } \\
\text { improvement }\end{array}$ \\
\hline Mohammadi $2012^{42}$ & 15 & $50 \mathrm{~Hz}$ & $1 \mathrm{~min}$ & $\begin{array}{l}\text { n.15 control } \\
\text { group }\end{array}$ & $\begin{array}{l}\text { Prevention of } \\
\text { musclesoreness }\end{array}$ \\
\hline Wheeler $2013^{45}$ & 10 & $30 \mathrm{~Hz}$ & $10 \mathrm{~min}$ & $\begin{array}{l}\text { n. } 10 \text { control } \\
\text { group }\end{array}$ & $\begin{array}{l}\text { No differences in } \\
\text { DOMS, flexibility, } \\
\text { or explosive } \\
\text { power }\end{array}$ \\
\hline Koh $2013^{43}$ & 20 & $20 \mathrm{~Hz}$ & $10 \mathrm{~min}$ & $\begin{array}{l}\text { n.20 } \\
\text { ultrasound } \\
\text { group } \\
\text { n.20 control } \\
\text { group }\end{array}$ & $\begin{array}{l}\text { Decreased } \\
\text { soreness }\end{array}$ \\
\hline Manimmanakorn $2015^{44}$ & 8 & $30-40 \mathrm{~Hz}$ & $10 \mathrm{~min}$ & $\begin{array}{l}\mathrm{n} .8 \text { active } \\
\text { recovery }\end{array}$ & $\begin{array}{l}\text { increased } \\
\text { muscle } \\
\text { oxygenation and } \\
\text { blood flow }\end{array}$ \\
\hline
\end{tabular}

metric and explosive knee extension strength preventing the age-related loss in skeletal muscle mass. These effects on muscular performance have a dramatic influence on patient mobility and balancing ability. Bautmans et al. in a randomized controlled trial (RCT) on institutionalized elderly found that 6-week static WBV exercise was beneficial for mobility ${ }^{54}$. Cheung et al. reported WBV to be effective in improving the balancing ability in elderly women. In addition he found that a simple WBV treatment protocol of 3 minutes a day was effective to maintain balancing ability and reduce the risk of fall55. Wang et al. demonstrated that a 3-month program combining WBV and quadriceps strengthening exercise improved symptoms, physical function and spatiotemporal parameters in patients with medial compartment knee osteoarthritis ${ }^{56}$. Similar outcomes were reported by Rabini et al. who randomized 50 patients with knee osteoarthritis showing improvement in all functional parameters at 6 months $\mathrm{FU}^{57}$. Opposite results were reported by Segal et al. who investigated the effects of WBV platforms in a group of asymptomatic middle-aged women with risk factors for knee $\mathrm{OA}^{58}$. In this population, the addition of vibration to a 12week exercise program did not result in significantly greater improvement in lower limb strength or power than did participation in the exercise program without vibration.
Clinical applications: children

Semler et al. evaluated the effects of high-intensity vibration (15-20 Hz, 1- $2 \mathrm{~mm}$ amplitude, $12 \mathrm{~g}$ ) combined with tilt-table exercise in a group of 8 children with osteogenesis imperfecta. After 6 months protocol significant improvements in muscle and ground reaction forces were observed 59 .

\section{Bone metabolism}

Osteoporosis is a disease of the skeletal system characterized by low bone mass and deterioration of bone tissue 60 . Osteoporosis affects $2 \%$ of men and $10 \%$ of women over the age of 50 in the U.S. ${ }^{61}$. WBV in this field was initially proposed to reduce bone density loss of astronauts in space ${ }^{62}$.

\section{Ways of action}

Several studies show that VS therapy improves bone circulation, increasing the supply of nutrients needed to build bones ${ }^{31,63}$. Vibration promotes osteogenic differentiation ${ }^{64}$, cell communication ${ }^{65}$, while reduces osteoclast formation ${ }^{66}$ and expression of osteoclastforming RANKL in osteocytes ${ }^{67}$, which is increased during unloading 68 .

\section{Clinical applications: bone metabolism}

A direct positive effect of WBV on calcium metabolism and bone mineral density (BMD) has been clear- 
Table 3. Clinical applications of WBV: elderly patients.

\begin{tabular}{|c|c|c|c|c|c|}
\hline Author & $\begin{array}{l}\text { n. of } \\
\text { patients }\end{array}$ & $\begin{array}{l}\text { Type of } \\
\text { vibration }\end{array}$ & Duration & Control group & Outcome \\
\hline Roelants $2004^{49}$ & 89 & $\begin{array}{l}\text { Vibration } \\
\text { platform }\end{array}$ & 24 weeks & $\begin{array}{l}\text { n. } 30 \text { resistance- } \\
\text { training group } \\
\text { n. } 29 \text { control } \\
\text { group }\end{array}$ & $\begin{array}{l}\text { Increased knee-extension } \\
\text { strength and speed of } \\
\text { movement }\end{array}$ \\
\hline Verschueren $2004^{51}$ & 25 & $35-40 \mathrm{~Hz}$ & 24 weeks & $\begin{array}{l}\text { n.22 resistance- } \\
\text { training group } \\
\text { n. } 23 \text { control } \\
\text { group }\end{array}$ & $\begin{array}{l}\text { Increased isometric and } \\
\text { dynamic muscle strength }\end{array}$ \\
\hline Bautmans $2005^{54}$ & 14 & $30-50 \mathrm{~Hz}$ & 6 weeks & $\begin{array}{l}\mathrm{n} .11 \text { Control } \\
\text { group }\end{array}$ & $\begin{array}{l}\text { Increased leg extension } \\
\text { Increased lower body } \\
\text { flexibility }\end{array}$ \\
\hline Roelants $2006^{50}$ & 15 & $35 \mathrm{~Hz}$ & $\begin{array}{l}\text { Single } \\
\text { session }\end{array}$ & No & $\begin{array}{l}\text { Increased activation of leg } \\
\text { muscles }\end{array}$ \\
\hline Bogaerts $2007^{53}$ & 31 & $40-40 \mathrm{HZ}$ & 44 weeks & $\begin{array}{l}\text { n.30 Fitness } \\
\text { group } \\
\text { n.36 Control } \\
\text { group }\end{array}$ & $\begin{array}{l}\text { Increased isometric muscle } \\
\text { strength and muscle mass }\end{array}$ \\
\hline Cheung $2007^{55}$ & 45 & $20 \mathrm{~Hz}$ & 12 weeks & $\begin{array}{l}\text { n.24 Control } \\
\text { group }\end{array}$ & $\begin{array}{l}\text { Increased stability, } \\
\text { movement velocity, } \\
\text { maximum point excursion, } \\
\text { directional control }\end{array}$ \\
\hline Pietrangelo $2009^{4}$ & 9 & $300 \mathrm{~Hz}$ & 12 weeks & No & $\begin{array}{l}\text { Increased maximal } \\
\text { isometric strength } \\
\text { No increase in muscle size } \\
\text { Changes in gene } \\
\text { exoression }\end{array}$ \\
\hline Bemben $2010^{52}$ & 21 & $30-40 \mathrm{~Hz}$ & 32 weeks & $\begin{array}{l}\mathrm{n} .22 \text { resistance- } \\
\text { training group } \\
\mathrm{n} .12 \text { control } \\
\text { group }\end{array}$ & $\begin{array}{l}\text { Increate muscular strength } \\
\text { Increased Hip adduction } \\
\text { and abduction }\end{array}$ \\
\hline Bellomo $2013^{46}$ & 10 & $300 \mathrm{~Hz}$ & 12 weeks & $\begin{array}{l}\text { n.10 Global } \\
\text { Sensorimotor } \\
\text { Training } \\
\text { n.10 Resistance } \\
\text { training } \\
\text { n.10 Control } \\
\text { group }\end{array}$ & Increased muscle strength \\
\hline Segal $2013^{58}$ & 26 & $35 \mathrm{~Hz}$ & 12 weeks & $\begin{array}{l}\text { n.13 Exercise } \\
\text { program }\end{array}$ & $\begin{array}{l}\text { No significant improvement } \\
\text { in lower limb strength or } \\
\text { power }\end{array}$ \\
\hline Wang $2015^{56}$ & 19 & $30 \mathrm{~Hz}$ & 16 weeks & $\begin{array}{l}\mathrm{n} .19 \text { quadriceps } \\
\text { strengthening } \\
\text { exercise }\end{array}$ & $\begin{array}{l}\text { Improvement in physical } \\
\text { function and spatio- } \\
\text { temporal parameters }\end{array}$ \\
\hline Rabini $2015^{57}$ & 25 & $100 \mathrm{~Hz}$ & 24 weeks & $\begin{array}{l}\text { n. } 25 \text { control } \\
\text { group }\end{array}$ & $\begin{array}{l}\text { Increased stability and } \\
\text { balance }\end{array}$ \\
\hline
\end{tabular}

ly demonstrated (Tab. 4). Rubin et al. carried on a RCT comparing the effects of low intensity vibration (LIV) (10 minutes twice a day) with those of an inactive placebo plate in a group of postmenopausal women $^{69}$. A decrease of $2 \%$ BMD was observed in the control group, whereas a $2.17 \%$ relative BMD increase was reported in the study group. Similar positive outcomes were reported with quantitative computed tomography ${ }^{70}$. An increase of $2 \%$ of trabecular and cortical bone was observed in those patients who received LIV compared with the inactive group. The major bias of the available literature on this specific issue is the low methodological quality and design of the studies. Most of them lack of control groups and widely differ in terms of intensity and duration of exposition to WBV. The effects of high-intensity vibration $(30 \mathrm{~Hz})$ for 10 min 5 days a week were investigated in a non-randomized controlled study on 116 postmenopausal women with osteoporosis ${ }^{71}$. An increase of lumbar and femoral neck BMD by 4.3 and 
Table 4. Clinical applications of WBV: bone metabolism.

\begin{tabular}{|c|c|c|c|c|c|}
\hline Author & $\begin{array}{l}\text { n. of } \\
\text { patients }\end{array}$ & $\begin{array}{l}\text { Type of } \\
\text { vibration }\end{array}$ & Duration & $\begin{array}{l}\text { Control } \\
\text { group }\end{array}$ & Outcome \\
\hline Rubin $2004^{69}$ & 35 & $\begin{array}{l}30 \mathrm{~Hz} \text { vertical } \\
\text { vibration }\end{array}$ & 52 weeks & n.35 placebo & $\begin{array}{l}2.7 \% \text { increase } \\
\text { of } B M D\end{array}$ \\
\hline Ward $2004^{63}$ & 10 & $90 \mathrm{~Hz}$ & 24 weeks & n.10 placebo & $\begin{array}{l}6.3 \% \text { increase } \\
\text { of BMD }\end{array}$ \\
\hline Gilsanz $2006^{70}$ & 24 & $30 \mathrm{~Hz}$ & 24 weeks & n. 24 placebo & $\begin{array}{l}2.1 \text { and } 3.4 \% \\
\text { increase in } \\
\text { lumbar and } \\
\text { femoral BMD }\end{array}$ \\
\hline Ruan $2008^{71}$ & 66 & $30 \mathrm{~Hz}$ & 24 weeks & n.50 placebo & $\begin{array}{l}3.2 \text { and } 4.3 \% \\
\text { increase in } \\
\text { femoral neck } \\
\text { and lumbar } \\
\text { BMD }\end{array}$ \\
\hline Slatkovska $2011^{73}$ & $67+68$ & $\begin{array}{l}30 \mathrm{~Hz} \\
90 \mathrm{~Hz}\end{array}$ & 52 weeks & n. 67 placebo & $\begin{array}{l}\text { No increase in } \\
\text { BMD }\end{array}$ \\
\hline Von Stengel $2011^{75}$ & 46 & $25-35 \mathrm{~Hz}$ & 80 weeks & $\begin{array}{l}\text { n. } 47 \text { training } \\
\text { group } \\
\text { n. } 48 \text { placebo }\end{array}$ & $\begin{array}{l}\text { No difference in } \\
\text { BMD } \\
\text { Reduced } n \text {. of } \\
\text { falls }\end{array}$ \\
\hline Von Stengel $2011^{76}$ & $\begin{array}{l}108 \text { rotational } \\
\text { vibration and } \\
\text { vertical } \\
\text { vibration }\end{array}$ & $\begin{array}{l}12.5 \mathrm{~Hz} \\
\text { rotational } \\
\text { vibration } \\
35 \mathrm{~Hz} \text { vertical } \\
\text { vibration }\end{array}$ & 52 weeks & control group & $\begin{array}{l}\text { Increased } \\
\text { lumbar }(0.5 \%) \\
\text { hip }(0.3 \%) \text { BMD } \\
\text { and leg } \\
\text { strength }\end{array}$ \\
\hline Zha $2012^{77}$ & 34 & $\begin{array}{l}45-55 \mathrm{~Hz} \\
\text { vertical } \\
\text { vibration }\end{array}$ & 24 weeks & n.33 placebo & $\begin{array}{l}\text { Increase in } \\
\text { BMD } \\
\text { (especially in } \\
\text { patients with } \\
\text { osteoporosis) }\end{array}$ \\
\hline Lai $2013^{72}$ & 14 & $30 \mathrm{~Hz}$ & 24 weeks & n.14 placebo & $\begin{array}{l}2 \% \text { increase in } \\
\text { lumbar } B M D\end{array}$ \\
\hline Lam $2013^{78}$ & 61 & $32-37 \mathrm{~Hz}$ & 52 weeks & n.63 placebo & $\begin{array}{l}\text { increase in } \\
\text { femoral neck } \\
\text { and lumbar } \\
\text { BMD }\end{array}$ \\
\hline Gomez Cabello $2014^{74}$ & 24 & $35 \mathrm{~Hz}$ & 11 weeks & n.25 placebo & $\begin{array}{l}\text { No changes in } \\
\text { DXA }\end{array}$ \\
\hline
\end{tabular}

$3.2 \%$ was observed. In a similar study, the application of $30 \mathrm{~Hz}$ for $10 \mathrm{~min}$ thrice weekly, showed an increase of $2 \%$ of lumbar spine BMD at 6 months, whereas control subjects experienced BMD reduction $^{72}$. Different results were observed in a randomized trial on 202 osteopenic postmenopausal women ${ }^{73}$. All patients received daily application of LIV (20 minutes) for 1 year, although in one group the intensity was $37 \mathrm{~Hz}$ and in the other it was $90 \mathrm{~Hz} \mathrm{No}$ significant differences were found in the tibial trabecular BMD or femoral neck, total hip, or lumbar spine BMD. The major bias of this study was the low-compliance rate in the two groups (65-79\%).

Several studies evaluated the effects of WBV in combination with dynamic exercise with contradictory results. Gomez-Cabello et al. in a randomized trial on 49 elderly subjects (either males or females) com- pared the outcomes of combined WBV $(35 \mathrm{~Hz}, \sim 16 \mathrm{~g})$ and trained squat three times a week for 11 weeks to a control group receiving no vibration or exercise program $^{74}$. No changes in dual-energy X-ray absorptiometry scan measures were found. Von Stengel et al. carried on a 18-month randomized trial on 151 postmenopausal women study comparing the outcomes of conventional training program with conventional training program associated with WBV and with wellness control group ${ }^{75}$. Vibration therapy combined with low-impact activity enhanced the effect of training alone in increasing lumbar BMD. In addition subjects in the vibration group had decreased falls (probably as a consequence of better neuromuscular control). The same Authors compared the effects of rotational vibration training (RVT) (three sessions per week, for $15 \mathrm{~min}$ ) associated with dynamic squat exercises, 
vertical vibration training (VVT) and a wellness control group $(C G)^{76}$. One hundred-eight postmenopausal women were reviewed after 12 months. Increase in lumbar spine BMD and maximum leg strength was observed in both vibration VT groups compared to CG. Another study investigated the effects of a 6-month protocol consisting of WBV (44-55 $\mathrm{Hz}, 0.5 \mathrm{~g})$ and alternative tilting performed three times per week ${ }^{77}$. Significantly BMD increases were reported in the study group that were higher in women compared with men, and in participants with osteoporosis, compared with those without low bone density.

In a similar way the effects of LIV on BMD have been studied in children with immobility-associated disability. Twenty disabled ambulant children were randomized to receive either LIV $(90 \mathrm{~Hz}, 0.3 \mathrm{~g}, 10 \mathrm{~min} /$ day, 5 days per week) or placebo ${ }^{63}$. At 6 months subjects in the study group showed $6.3 \%$ increase in BMD, whereas those in the control group had a decrease of $12 \%$. As reported in other studies the compliance rate was low (44\%). The influence of WBV on BMD was assessed in 149 osteopenic children with idiopathic scoliosis ${ }^{78}$. Subjects in the study group had low-magnitude, high-frequency WBV $(32-37 \mathrm{~Hz}, 0.3 \mathrm{~g})$ for 20 $\mathrm{min} /$ day, 5 days weekly for 12 months. The treatment group showed significant increases in femoral neck $\mathrm{BMD}$ and an increase in lumbar spine bone compared with controls. These studies suggest that vibration has greater anabolic potential in the growing subjects probably influencing the activity of a more robust mesenchimal stem cells (MSC) pool.

\section{Technical considerations}

Although most of the studies show positive effects of vibration therapy on muscle function, physical performance, patient mobility and balancing and bone density, some series report contradictory outcomes. These wide differences may be the consequence of multiple devices used in clinical trials. These devices have different directionality (horizontal displacement, side-to-side or vertical), amplitudes (displacements resulting in gravitational force from less than 1 to greater than $15 \mathrm{~g})$, and frequency $(5-90 \mathrm{~Hz})^{79}$. Some evidence suggests that muscle tension increases linearly with vibration frequency ${ }^{17}$ and a $30-50 \mathrm{~Hz}$ frequency is appropriate ${ }^{80}$. On the contrary, there is no evidence that high-intensity vibration performs better than low-intensity vibration, and may lead to adverse effects. On the contrary in some cases, high-intensity vibration was responsible for muscle damage, back and joint pain ${ }^{81}$. The effects of frequency and intensity of the vibration are more important for local VS, than for WBV where the additional the changes in gravitational load play an additional role ${ }^{5}$. When selecting a treatment regimen, it is recommended to use devices that clearly report the vibration parameters and that deliver low-intensity $(<1 \mathrm{~g})$, horizontal displacements at high frequencies $(30-100 \mathrm{~Hz})^{12}$.

\section{Conclusion}

Vibration therapy provides anabolic mechanical signals to bone and musculo-tendinous system. They mimic motion and exercise positively influencing muscle function and coordination. The influence on bone metabolism is achieved through mechanical regulation of mesenchymal stem cells, which provide progenitors for bone growth. Although no universal consensus exists on the ideal protocol to adopt, delivering low-magnitude high-intensity mechanical signals mimic the physiologic stimuli the human body has to deal with in daily life. This would ensure safe effects comparable to mild exercise programs.

\section{Conflict of interests}

The Authors declare that they have no conflict of interests regarding the publication of this paper.

\section{References}

1. J W. The law of transformation of bone. Kirschwald. 1892.

2. Fritton SP, McLeod KJ, Rubin CT. Quantifying the strain history of bone: spatial uniformity and self-similarity of low-magnitude strains. Journal of biomechanics. 2000;33(3):317-325.

3. Chan ME, Uzer G, Rubin CT. The potential benefits and inherent risks of vibration as a non-drug therapy for the prevention and treatment of osteoporosis. Current osteoporosis reports. 2013;11(1):36-44.

4. Pietrangelo T, Mancinelli R, Toniolo L, et al. Effects of local vibrations on skeletal muscle trophism in elderly people: mechanical, cellular, and molecular events. International journal of molecular medicine. 2009;24(4):503-512.

5. Cardinale M, Lim J. Electromyography activity of vastus lateralis muscle during whole-body vibrations of different frequencies. Journal of strength and conditioning research/National Strength \& Conditioning Association. 2003;17(3):621-624.

6. Lundberg TNR, Ottoson D. Pain alleviation by vibratory stimulation. Pain. 1984;20:25-44.

7. Bongiovanni LG, Hagbarth KE, Stjernberg L. Prolonged muscle vibration reducing motor output in maximal voluntary contractions in man. The Journal of physiology. 1990;423: 15-26.

8. Houston MN, Hodson VE, Adams KK, Hoch JM. The effectiveness of whole-body-vibration training in improving hamstring flexibility in physically active adults. Journal of sport rehabilitation. 2015;24(1):77-82.

9. Gusi N, Raimundo A, Leal A. Low-frequency vibratory exercise reduces the risk of bone fracture more than walking: a randomized controlled trial. BMC musculoskeletal disorders. 2006;7:92.

10. Ahlborg L, Andersson C, Julin P. Whole-body vibration training compared with resistance training: effect on spasticity, muscle strength and motor performance in adults with cerebral palsy. Journal of rehabilitation medicine. 2006;38(5):302-308.

11. Saggini R, Vecchiet J, lezzi S, et al. Submaximal aerobic exercise with mechanical vibrations improves the functional status of patients with chronic fatigue syndrome. Europa medicophysica. 2006;42(2):97-102.

12. Thompson WR, Yen SS, Rubin J. Vibration therapy: clinical applications in bone. Current opinion in endocrinology, diabetes, and obesity. 2014;21(6):447-453. 
13. Padulo J, Oliva F, Frizziero A, Maffulli N. Muscles, Ligaments and Tendons Journal. Basic principles and recommendations in clinical and field science research. MLTJ. 2013;3(4):250252.

14. Kvorning T, Bagger M, Caserotti $P$, Madsen K. Effects of vibration and resistance training on neuromuscular and hormonal measures. European journal of applied physiology. 2006;96(5):615-625.

15. Di Loreto CRA, Lucidi P, Murdolo G, et al. Effects of wholebody vibration exercise on the endocrine system of healthy men. J Endocrinol Invest. 2004;27(4):323-327.

16. Eklund G, Hagbarth KE. Normal variability of tonic vibration reflexes in man. Experimental neurology. 1966;16(1):80-92.

17. Matthews PB. The reflex excitation of the soleus muscle of the decerebrate cat caused by vibbration applied to its tendon. The Journal of physiology. 1966;184(2):450-472.

18. Issurin VB. Vibrations and their applications in sport. A review. The Journal of sports medicine and physical fitness. 2005;45 (3):324-336

19. Cardinale $M, B$ Bosco $C$. The use of vibration as an exercise intervention. Exercise and sport sciences reviews. 2003;31(1): 3-7.

20. Bosco C, lacovelli M, Tsarpela O, et al. Hormonal responses to whole-body vibration in men. European journal of applied physiology. 2000;81(6):449-454.

21. Seidel H. Myoelectric reactions to ultra-low frequency and lowfrequency whole body vibration. European journal of applied physiology and occupational physiology. 1988;57(5):558-562.

22. Milner-Brown HS, Stein RB, Lee RG. Synchronization of human motor units: possible roles of exercise and supraspinal reflexes. Electroencephalography and clinical neurophysiology. 1975;38(3):245-254 .

23. Iodice P, Bellomo RG, Gialluca G, Fano G, Saggini R. Acute and cumulative effects of focused high-frequency vibrations on the endocrine system and muscle strength. European journal of applied physiology. 2011;111(6):897-904.

24. Ahtiainen JP, Pakarinen A, Alen M, Kraemer WJ, Hakkinen K. Muscle hypertrophy, hormonal adaptations and strength development during strength training in strength-trained and untrained men. European journal of applied physiology. 2003;89 (6):555-563.

25. Petit J, Filippi GM, Gioux M, Hunt CC, Laporte Y. Effects of tetanic contraction of motor units of similar type on the initial stiffness to ramp stretch of the cat peroneus longus muscle. Journal of neurophysiology. 1990;64(6):1724-1732.

26. Lephart SM, Henry TJ. Functional rehabilitation for the upper and lower extremity. The Orthopedic clinics of North America. 1995;26(3):579-592.

27. Liu-Ambrose T, Taunton JE, MacIntyre D, McConkey P, Khan $\mathrm{KM}$. The effects of proprioceptive or strength training on the neuromuscular function of the ACL reconstructed knee: a randomized clinical trial. Scandinavian journal of medicine \& science in sports. 2003;13(2):115-123.

28. Keller BV, Davis ML, Thompson WR, Dahners LE, Weinhold PS. Varying whole body vibration amplitude differentially affects tendon and ligament structural and material properties. Journal of biomechanics. 2013;46(9):1496-1500.

29. Bosco C, Cardinale M, Tsarpela O. Influence of vibration on mechanical power and electromyogram activity in human arm flexor muscles. European journal of applied physiology and occupational physiology. 1999;79(4):306-311.

30. Issurin VB, Tenenbaum G. Acute and residual effects of vibratory stimulation on explosive strength in elite and amateur athletes. Journal of sports sciences. 1999;17(3):177-182.

31. Torvinen S, Kannu P, Sievanen $\mathrm{H}$, et al. Effect of a vibration exposure on muscular performance and body balance. Randomized cross-over study. Clinical physiology and functional imaging. 2002;22(2):145-152.
32. Rittweger J, Beller G, Felsenberg D. Acute physiological effects of exhaustive whole-body vibration exercise in man. Clinical physiology. 2000;20(2):134-142.

33. De Ruiter CJ, van der Linden RM, van der Zijden MJ, Hollan$\operatorname{der}$ AP, de Haan A. Short-term effects of whole-body vibration on maximal voluntary isometric knee extensor force and rate of force rise. European journal of applied physiology. 2003;88(45):472-475.

34. Mottram CJ, Maluf KS, Stephenson JL, Anderson MK, Enoka RM. Prolonged vibration of the biceps brachii tendon reduces time to failure when maintaining arm position with a submaximal load. Journal of neurophysiology. 2006;95(2):1185-1193.

35. Necking LE, Friden J, Lundborg G. Reduced muscle strength in abduction of the index finger: an important clinical sign in hand-arm vibration syndrome. Scandinavian journal of plastic and reconstructive surgery and hand surgery. 2003;37(6):365370.

36. Jackson SW, Turner DL. Prolonged muscle vibration reduces maximal voluntary knee extension performance in both the ipsilateral and the contralateral limb in man. European journal of applied physiology. 2003;88(4-5):380-386.

37. Saggini RSN, Bellomo RG, Dessy RA, Cancelli F, lodice P. Selective development of muscular force in the rehabilitative context. Europa medicophysica. 2006;42 (suppl.1):69-72.

38. Rhea MR, Bunker D, Marin PJ, Lunt K. Effect of Tonic wholebody vibration on delayed-onset muscle soreness among untrained individuals. Journal of strength and conditioning research/National Strength \& Conditioning Association. 2009;23 (6):1677-1682.

39. Aminian-Far A, Hadian MR, Olyaei G, Talebian S, Bakhtiary $\mathrm{AH}$. Whole-body vibration and the prevention and treatment of delayed-onset muscle soreness. Journal of athletic training. 2011;46(1):43-49.

40. Lau WY, Nosaka K. Effect of vibration treatment on symptoms associated with eccentric exercise-induced muscle damage. American journal of physical medicine \& rehabilitation/Association of Academic Physiatrists. 2011;90(8):648-657.

41. Broadbent S, Rousseau JJ, Thorp RM, Choate SL, Jackson FS, Rowlands DS. Vibration therapy reduces plasma IL6 and muscle soreness after downhill running. British journal of sports medicine. 2010;44(12):888-894.

42. Mohammadi $\mathrm{H}$, Sahebazamani $\mathrm{M}$. Influence of vibration on some of functional markers of delayed onset muscle soreness. International Journal of Applied Exercise Physiology. 2012.

43. Koh HW, Cho SH, Kim CY, Cho BJ, Kim JW, Bo KH. Effects of vibratory stimulations on maximal voluntary isometric contraction from delayed onset muscle soreness. Journal of physical therapy science. 2013;25(9):1093-1095.

44. Manimmanakorn N, Ross JJ, Manimmanakorn A, Lucas SJ, Hamlin MJ. Effect of whole-body vibration therapy on performance recovery. International journal of sports physiology and performance. 2015;10(3):388-395.

45. Wheeler AA, Jacobson BH. Effect of whole-body vibration on delayed onset muscular soreness, flexibility, and power. Journal of strength and conditioning research/National Strength \& Conditioning Association. 2013;27(9):2527-2532.

46. Bellomo RG, Maffulli N, Maghradze T, Coco V, Saggini R. Muscle Strength and Balance Training in Sarcopenic Elderly: A Pilot Study with Randomized Controlled Trial. European Journal of Inflammation. 2013:11(1):193-201.

47. Fiatarone MA, Marks EC, Ryan ND, Meredith CN, Lipsitz LA, Evans WJ. High-intensity strength training in nonagenarians. Effects on skeletal muscle. Jama. 1990;263(22): 3029-3034.

48. Frontera WR, Meredith CN, O'Reilly KP, Knuttgen HG, Evans WJ. Strength conditioning in older men: skeletal muscle hypertrophy and improved function. J Appl Physiol (1985). 1988; 64(3):1038-1044. 
49. Roelants M, Delecluse C, Verschueren SM. Whole-body-vibration training increases knee-extension strength and speed of movement in older women. Journal of the American Geriatrics Society. 2004;52(6):901-908.

50. Roelants M, Verschueren SM, Delecluse C, Levin O, Stijnen V. Whole-body-vibration-induced increase in leg muscle activity during different squat exercises. Journal of strength and conditioning research /National Strength \& Conditioning Association. 2006;20(1):124-129.

51. Verschueren SM, Roelants M, Delecluse C, Swinnen S, Vanderschueren D, Boonen S. Effect of 6-month whole body vibration training on hip density, muscle strength, and postural control in postmenopausal women: a randomized controlled pilot study. Journal of bone and mineral research: the official journal of the American Society for Bone and Mineral Research. 2004;19(3):352-359.

52. Bemben DA, Palmer IJ, Bemben MG, Knehans AW. Effects of combined whole-body vibration and resistance training on muscular strength and bone metabolism in postmenopausal women. Bone. 2010;47(3):650-656.

53. Bogaerts A, Delecluse C, Claessens AL, Coudyzer W, Boonen S, Verschueren SM. Impact of whole-body vibration training versus fitness training on muscle strength and muscle mass in older men: a 1-year randomized controlled trial. The journals of gerontology Series A, Biological sciences and medical sciences. 2007;62(6):630-635.

54. Bautmans I, Van Hees E, Lemper JC, Mets T. The feasibility of Whole Body Vibration in institutionalised elderly persons and its influence on muscle performance, balance and mobility: a randomised controlled trial [ISRCTN62535013]. BMC geriatrics. 2005;5:17.

55. Cheung WH, Mok HW, Qin L, Sze PC, Lee KM, Leung KS. High-frequency whole-body vibration improves balancing ability in elderly women. Archives of physical medicine and rehabilitation. 2007;88(7):852-857.

56. Wang $\mathrm{P}$, Yang L, Li H, et al. Effects of whole-body vibration training with quadriceps strengthening exercise on functioning and gait parameters in patients with medial compartment knee osteoarthritis: a randomised controlled preliminary study. Physiotherapy. 2015.

57. Rabini A, De Sire A, Marzetti E, et al. Effects of focal muscle vibration on physical functioning in patients with knee osteoarthritis: a randomized controlled trial. European journal of physical and rehabilitation medicine. 2015;51(5):513-520.

58. Segal NA, Glass NA, Shakoor N, Wallace R. Vibration platform training in women at risk for symptomatic knee osteoarthritis. PM \& R: the journal of injury, function, and rehabilitation. 2013;5(3):201-209; quiz 9.

59. Semler O, Fricke O, Vezyroglou K, Stark C, Stabrey A, Schoenau $E$. Results of a prospective pilot trial on mobility after whole body vibration in children and adolescents with osteogenesis imperfecta. Clinical rehabilitation. 2008;22(5):387-394.

60. (US) Oot SG. Bone Health and Osteoporosis: A Report of the Surgeon General 2004.

61. Looker AC, Melton LJ 3rd, Harris TB, Borrud LG, Shepherd JA. Prevalence and trends in low femur bone density among older US adults: NHANES 2005-2006 compared with NHANES III. Journal of bone and mineral research: the official journal of the American Society for Bone and Mineral Research. 2010;25(1): 64-71.

62. Rubin $\mathrm{C}, \mathrm{Xu} \mathrm{G}$, Judex $\mathrm{S}$. The anabolic activity of bone tissue, suppressed by disuse, is normalized by brief exposure to extremely low-magnitude mechanical stimuli. FASEB journal: official publication of the Federation of American Societies for Experimental Biology. 2001;15(12):2225-2229.

63. Ward K, Alsop C, Caulton J, Rubin C, Adams J, Mughal Z. Low magnitude mechanical loading is osteogenic in children with disabling conditions. Journal of bone and mineral research : the official journal of the American Society for Bone and Mineral Research. 2004;19(3):360-369.

64. Pre D, Ceccarelli G, Gastaldi G, et al. The differentiation of human adipose-derived stem cells (hASCs) into osteoblasts is promoted by low amplitude, high frequency vibration treatment. Bone. 2011;49(2):295-303.

65. Uzer G, Pongkitwitoon S, lan C, et al. Gap junctional communication in osteocytes is amplified by low intensity vibrations in vitro. PloS one. 2014;9(3):e90840.

66. Kulkarni RN, Voglewede PA, Liu D. Mechanical vibration inhibits osteoclast formation by reducing DC-STAMP receptor expression in osteoclast precursor cells. Bone. 2013;57(2): 493-8.

67. Lau E, Al-Dujaili S, Guenther A, Liu D, Wang L, You L. Effect of low-magnitude, high-frequency vibration on osteocytes in the regulation of osteoclasts. Bone. 2010;46(6):1508-1515.

68. Xiong J, Onal M, Jilka RL, Weinstein RS, Manolagas SC, O'Brien CA. Matrix-embedded cells control osteoclast formation. Nature medicine. 2011;17(10):1235-1241.

69. Rubin C, Recker R, Cullen D, Ryaby J, McCabe J, McLeod K. Prevention of postmenopausal bone loss by a low-magnitude, high-frequency mechanical stimuli: a clinical trial assessing compliance, efficacy, and safety. Journal of bone and mineral research: the official journal of the American Society for Bone and Mineral Research. 2004;19(3):343-351.

70. Gilsanz V, Wren TA, Sanchez M, Dorey F, Judex S, Rubin C Low-level, high-frequency mechanical signals enhance musculoskeletal development of young women with low BMD. Journal of bone and mineral research: the official journal of the American Society for Bone and Mineral Research. 2006;21(9):1464-1474.

71. Ruan XY, Jin FY, Liu YL, Peng ZL, Sun YG. Effects of vibration therapy on bone mineral density in postmenopausal women with osteoporosis. Chinese medical journal. 2008;121 (13):1155-1158.

72. Lai CL, Tseng SY, Chen CN, et al. Effect of 6 months of whole body vibration on lumbar spine bone density in postmenopausal women: a randomized controlled trial. Clinical interventions in aging. 2013;8:1603-1609.

73. Slatkovska L, Alibhai SM, Beyene J, Hu H, Demaras A, Cheung AM. Effect of 12 months of whole-body vibration therapy on bone density and structure in postmenopausal women: a randomized trial. Annals of internal medicine. 2011;155(10): 668-679.

74. Gomez-Cabello A, Gonzalez-Aguero A, Morales S, Ara I, Casajus JA, Vicente-Rodriguez G. Effects of a short-term whole body vibration intervention on bone mass and structure in elderly people. Journal of science and medicine in sport/Sports Medicine Australia. 2014;17(2):160-164.

75. Von Stengel S, Kemmler W, Engelke K, Kalender WA. Effects of whole body vibration on bone mineral density and falls: results of the randomized controlled ELVIS study with postmenopausal women. Osteoporosis international: a journal established as result of cooperation between the European Foundation for Osteoporosis and the National Osteoporosis Foundation of the USA. 2011;22(1):317-325.

76. Von Stengel S, Kemmler W, Bebenek M, Engelke K, Kalender WA. Effects of whole-body vibration training on different devices on bone mineral density. Medicine and science in sports and exercise. 2011;43(6):1071-1079.

77. Zha DS, Zhu QA, Pei WW, et al. Does whole-body vibration with alternative tilting increase bone mineral density and change bone metabolism in senior people? Aging clinical and experimental research. 2012;24(1):28-36.

78. Lam TP, Ng BK, Cheung LW, Lee KM, Qin L, Cheng JC. Effect of whole body vibration (WBV) therapy on bone density and bone quality in osteopenic girls with adolescent idiopathic scoliosis: a randomized, controlled trial. Osteoporosis 
international: a journal established as result of cooperation between the European Foundation for Osteoporosis and the National Osteoporosis Foundation of the USA. 2013;24(5): 1623-1636.

79. Rauch F, Sievanen H, Boonen S, et al. Reporting whole-body vibration intervention studies: recommendations of the International Society of Musculoskeletal and Neuronal Interactions. Journal of musculoskeletal \& neuronal interactions. 2010;10 (3):193-198.
80. Warman G, Humphries B, Purton J. The effects of timing and application of vibration on muscular contractions. Aviation, space, and environmental medicine. 2002;73(2):119-127.

81. Rittweger J, Schiessl H, Felsenberg D. Oxygen uptake during whole-body vibration exercise: comparison with squatting as a slow voluntary movement. European journal of applied physiology. $2001 ; 86(2): 169-173$. 